\title{
THE CHANGES IN PRECIPITATION DURING 124 YEARS AND ITS INFLUENCES ON THE PHYSICAL CONDITIONS OF HERNÁD RIVER
}

\author{
KOZMA, K. ${ }^{1}$ - PUSKÁS, J. ${ }^{1}$ - DRÉGELYI-KISS, Á. ${ }^{2} *$ \\ ${ }^{1}$ University of West Hungary, Institute of Geography and Environmental Sciences \\ 9700 Szombathely Károlyi Gáspár Square 4. \\ (phone: +36-94-504-306) \\ ${ }^{2}$ Óbuda University, Faculty of Bánki Donát Mechanical and Safety Engineering \\ 1081 Budapest, Népszínház u. 8. I./120. \\ (phone: +36-1-666-5397) \\ *Corresponding author \\ e-mail:dregelyi.agota@bgk.uni-obuda.hu \\ (Received $25^{\text {th }}$ Feb 2014; accepted $22^{\text {nd }}$ July 2014)
}

\begin{abstract}
Natural factors affect not only surroundings on River Hernád, but the appearance of people and their activities as well. These factors have significant effect on both the natural landscape and the river meandering processes. Recently, an intensive destruction level was measured concerning river banks in the selected area. By the comparison of historical maps and the GPS measurements in that region, the movements of the river basin have been reconstructed. The results show a displacement volume of 4-6 meters in some places within few years. The natural factors (precipitation, water levels) were examined as well as anthropogenic factors and their relationships. Research results demonstrate interaction of certain environmental elements. This study compares daily changes of precipitation data for hundred and twentyfour years through analysing the recorded water level of River Hernád. The high amount of river bank destruction is mainly caused by water level fluctuations, significant decrease in regional precipitation, and both type and intensity of cultivation.
\end{abstract}

Keywords: precipitation, water level, meandering, River Hernád

\section{Introduction}

In the floodplain of the river's Hungarian sections approximately 30 settlements face a constant threat of floods. Next to overflow, floods have a strong effect on the river's running line. On the other hand changes in the running line itself have knock-on effects on posterior flood-incidents that they provide a positive feedback. It is also important to define that directly or indirectly the same factors can cause flowages dissolved in the area where sporadic high banks are along the river-bed. Sometimes, this can result catastrophic damages or disasters. Devastating effects do not only appear on high bankdescents. By slipping into the river-bed mass of soil the running line of the river is changing next to causing damages in some gardens or other parts of local habitations. It can even block the total river-bed.

Therefore, monitoring the development of a river with mainly meandering sections in Hungary and forecasting their prospective changes are crucial for both theory and practice. Lately, geomorphologic research work in Hernád valley has been focused on the development of river banks. Important investigations were carried out by authors of recent study parallel with a research team of geomorphologists at the University of Szeged. Common research and consulting were often applied (Kiss et al., 2009; Blanka 
\& Kiss, 2010; Szabó, 2008; Kozma, 2008; Kozma \& Puskás, 2012; Kalmár \& Kozma, 2012).

Concerning regulation on Hernád several activities were implemented in the Hungarian part of the river valley over last hundred years. They have interfered with natural processes-related to the river-bed as well as with its surroundings. Join of streams as Kis-Hernád and Bársonyos-creek has been providing a good example for this theory. Its building-up took place at the end of the $18^{\text {th }}$, early $19^{\text {th }}$ century. Earlier, moorland surrounded this area where water streams of Hernád could have expanded. This phenomenon disappeared completely after having established the Bársonyos millchannel. Afterwards its side-streams also become regulated and their waters were directed into the river entirely. The regulation of left-side streams (Gönczi-creek 192830, Becsali-creek 1930) took place from 1930 to 1931, ones of right-side (Vasonczacreek and Vadász-creek (1928-30), a Bélus-brook and Garadna-creek (1930-31) from 1928 to 1931 (Trummer, 1933). In Slovakia some significant water storages and damming plants were built up in the last century having a profound impact on the regime of the river (Fig. 1, Table 1).

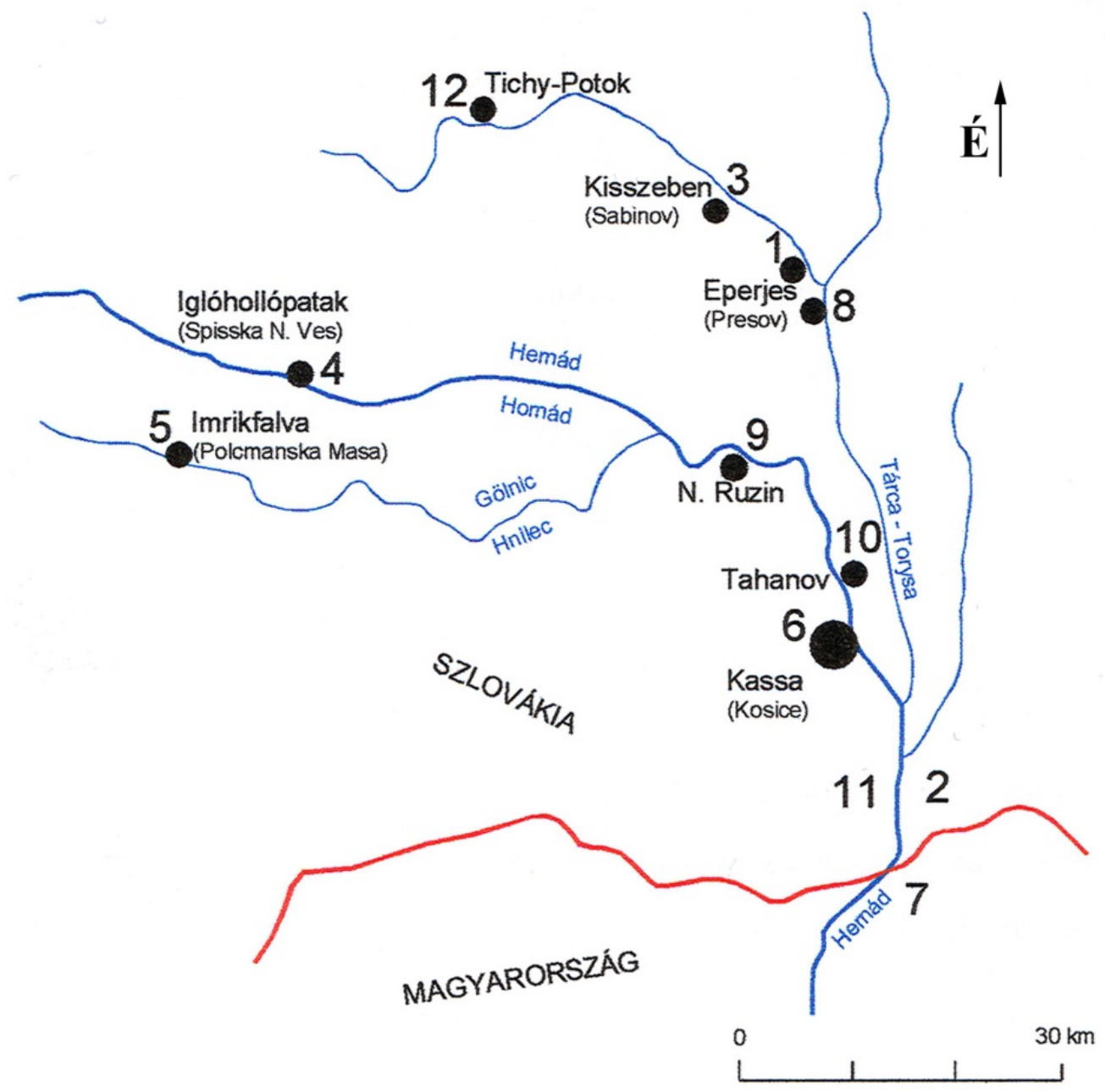

Figure 1. Location of the reservoirs and weirs on the catchment area of Hernád in Slovakia (on basis SHMÚ Pozsony/Bratislava and RVT 1998)(The numbers show the water facilities (Table 1) 
Table 1. Data of water facilities on Hernád in Slovakia

\begin{tabular}{c|c|c|c|c|c|c|c} 
& Facilities & Construction & Stream & Settlement & Function & $\begin{array}{c}\text { Important } \\
\text { data }\end{array}$ \\
1. & $\begin{array}{c}\text { hydart } \\
\text { pondectric } \\
\text { power }\end{array}$ & & 1904 & $\begin{array}{c}\text { Tárca } \\
\text { (Torysa) }\end{array}$ & $\begin{array}{c}\text { Eperjes } \\
\text { (Presov) }\end{array}$ & E & - \\
\hline 2. & channelization & & 1910 & Hernád & & A & $\begin{array}{c}\text { cut across } \\
10 \text { meander }\end{array}$ \\
\hline 3. & $\begin{array}{c}\text { hydroelectric } \\
\text { power }\end{array}$ & & 1912 & Tárca & $\begin{array}{c}\text { Kisszeben } \\
\text { (Sabinov) }\end{array}$ & E & - \\
\hline 4. & $\begin{array}{c}\text { hydroelectric } \\
\text { power (HP) }\end{array}$ & 1914 & Hernád & $\begin{array}{c}\text { Iglóhollópatak } \\
\text { (Spisska N. Ves) }\end{array}$ & E & - \\
\hline 5. & reservoir & 1948 & 1954 & $\begin{array}{c}\text { Gölnic } \\
\text { (Hlinec) }\end{array}$ & $\begin{array}{c}\text { Imrikfalva } \\
\text { (Polcmanska } \\
\text { Masa) }\end{array}$ & E, Ip, Iv & $\begin{array}{c}\text { T=11.046+ } \\
\text { HP }\end{array}$ \\
\hline 6. & weir & 1956 & 1961 & Hernád & $\begin{array}{c}\text { Kassa } \\
\text { (Kosice) }\end{array}$ & E & - \\
\hline 7. & channelization & 1962 & 1963 & Hernád & Hidasnémeti & A & - \\
\hline 8. & weir & 1967 & 1969 & Tárca & Eperjes & E & - \\
\hline 9. & reservoir & & 1972 & Hernád & $\begin{array}{c}\text { Óruzsin } \\
\text { (Nad Ruzin) }\end{array}$ & E, A & + HP \\
\hline 10. & reservoir & 1962 & 1973 & Hernád & next to Kassa & E, Ip, Iv & T=59.0 \\
\hline 11. & $\begin{array}{c}\text { river bank } \\
\text { protection }\end{array}$ & & 1975 & Hernád & & A & - \\
\hline 12. & reservoir & 1979 & 1982 & Tárca & Tichy Potok & Iv & T=19.6
\end{tabular}

$\mathrm{A}=$ flood prevention, $\mathrm{E}=$ energy production, $\mathrm{Ip}=$ industrial water supply, $\mathrm{IV}=$ drinking water supply, $\mathrm{T}=$ reservoir volume $\left(10^{6} \mathrm{~m}^{3}\right)$

Now there are four dams in the Hungarian sections of river. Three of them (Hernádszurdok, Gibárt and Felsődobsza) are located in top and middle river sections. However hydro-electric generators are operated with water flow, they do not have an enormous impact on their direct surroundings. They do not have any significant impacts on flood processes either (Konecsny, 2011). Researchers investigated meandering activities of river more as a "natural" function over last fifty years. These investigations took the artificial intervention-related modifications into consideration (Szabó, 2008; Kozma, 2008; Kiss et al., 2009; Blanka \& Kiss, 2010; Szabó et al., 2011; Kozma \& Puskás, 2012; Kalmár \& Kozma, 2012). With the appearance of extreme flood situations a new space for research work has been created concerning the river. A great number of studies have been published focusing on river's meandering activities applying a morphological approach for research objectives. Nevertheless, there have been such incidences lately that researchers should not avoid. For example the land use in this territory, which turned into the intensive agriculture or the extreme weather events usually experienced. The enormously transformations of both factors could evoke significant changes concerning natural processes of the river.

There are extreme variations in climate not only global or on nationwide level but some smaller regions are also involved recently. The volume of changes can turn into extreme posing indirect effects on other natural processes (Drégelyi-Kiss et al., 2008). Last few decades high precipitation amounts became more frequent, a quarter or even a third of national average of $600 \mathrm{~mm}$ could be falling within a single month (Rakonczai \& Ladányi, 2010). Moreover all that rain can happen within a simple hour. According to an IPCC report, this growing frequency of extreme precipitation conditions could risk 
both climate and agriculture in several regions. Studies published by Bartholy \& Pongrácz $(2005,2008)$ described such changes in the Carpathian Basin that reflected to these facts. They concluded that the "high" precipitation proportion on rainy days was significantly increasing by the fourth quarter of twentieth century however the number of rainy days was lower than before.

The meandering activity of River Hernád has been posing lots of questions and it is giving researchers a constant work. One of the researched areas is the field of dams in Slovakia that have a significant impact on its total passage. Authors do not have concrete data neither about the number of dam-ups nor its volume. Therefore a modelsituation was performed taking into consideration the characteristic factors and indicators related to river sections in Hungary. The quantity of precipitation concerning the Hungarian river sections was analysed in the period of 1890-2013 as well as the elevations of water in the relevant field between 1946 and 2011. The main objectives of these analyses were to identify substantial changes in terms of key factors and indicators as well as to determine effects on river-related natural processes. Furthermore, the different land-uses in the relevant areas were also investigated to be able to realise their impacts.

\section{Materials and Methods}

The Hernád valley - located in North-Hungary - shows a unique character. Not only the tectonic movements in the Quaternary and Tertiary periods contributed to geomorphic evolution, but fluvial action also had an important role, which intensively shape the landscape of the river and its surroundings.

The length of the Hungarian section of the River Hernád is $118 \mathrm{~km} .22 \%$ of the total length of the river is channelized. Our study area is about 20 kilometres long along the lower river section (Fig. 2). This territory was chosen, because the effects of river regulations between 1908 and 1972 did not influence this reach. The study area still has natural conditions, because it can be experienced only negligible effects of river regulation. Further reasons of our selection is that this territory is sparsely populated and it do not influence the natural conditions there. The bank collapses are very spectacular along this section of the river.

Our examination methods consist of field measurements and in addition, processing regular data precipitation, facts and figures with daily and monthly bases were registered and analysed embracing a total period of a hundred and twenty-four years. Graphically described results have become available as well. Concerning precipitation data of Hidasnémeti, the issues of National Meteorological Service (Hajósy et al., 1975) until 1970 provided a great source, from 1971 daily meteorological reports were used, which were published by National Meteorological Service.

Annual precipitation volumes and tendencies had been analysed from 1890 to 2013, and monthly precipitation were evaluated as a result. With appraisal work data over a hundred and twenty-four years were divided into four smaller sections, each of them involving thirty years. This kind of sectioning was based on the definition of WMO (World Meteorological Organization) that counted a period of 30 years to be compatible with character references of climate (IPCC, 2007). Data from last sixty-five years in terms of the daily elevation of water were added to these results applying Minitab v14 statistic software for data processing. 


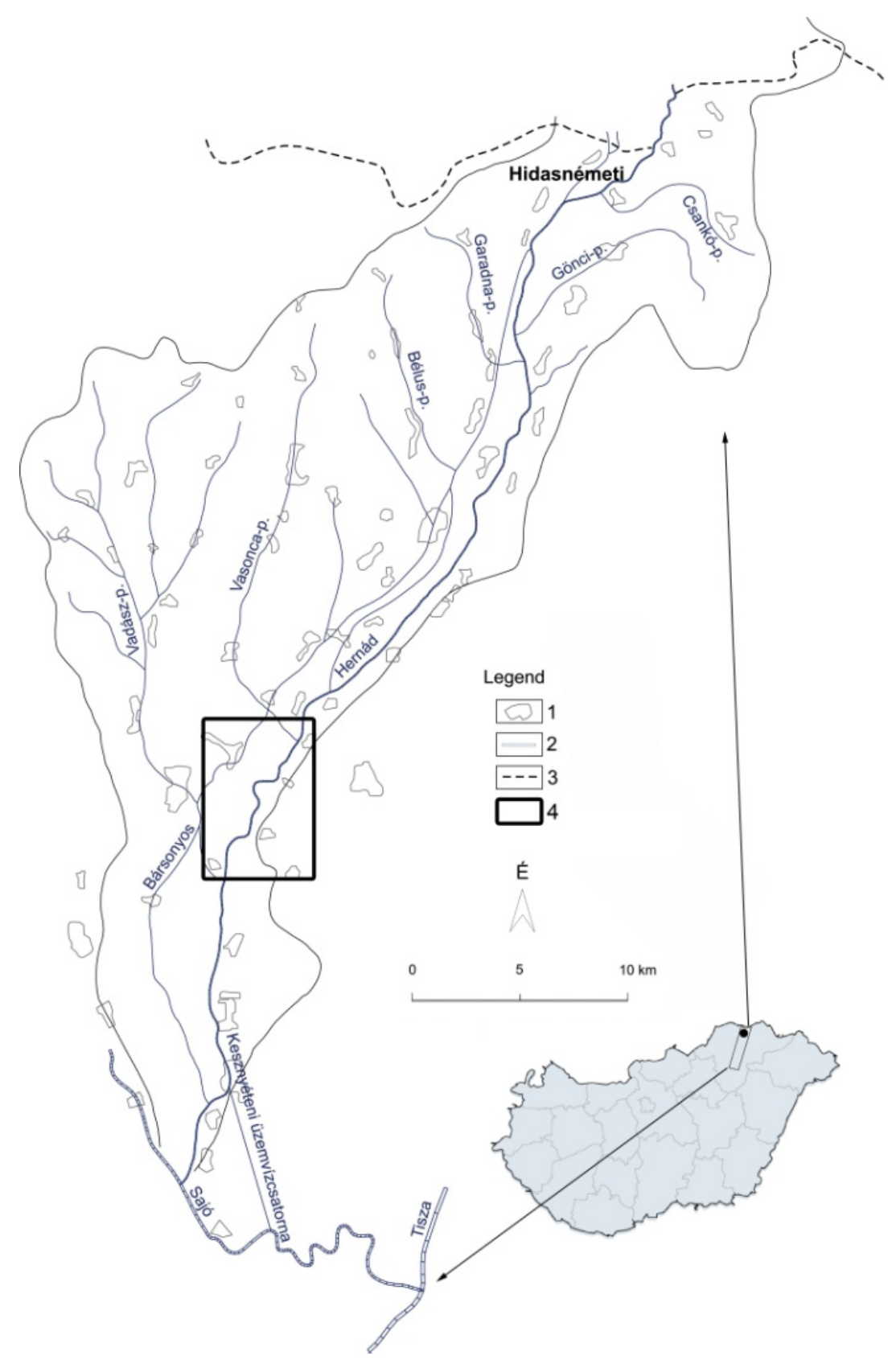

Figure 2. Catchment area of the river Hernád

1. settlement, 2. watercourse, 3. Hungarian border, 4. research area

\section{Results}

Based on the evaluation of precipitation data over more than a hundred years it is evident that total amount shows a declining tendency. The quantity of precipitation has been reduced by $0.23 \mathrm{~mm}$ a year (Fig. 3). These results are in accordance with the hypothesis that a slow dry-up period has begun in the Carpathian Basin (IPCC 2011; Bartholy \& Pongrácz, 2008; Horváth, 2009). Szász (1994) had some similar conclusions in his work. He expressed a definite descending tendency while he was analysing it in Hungary by assembling and comparing precipitation data of major meteorological sampling sites. 


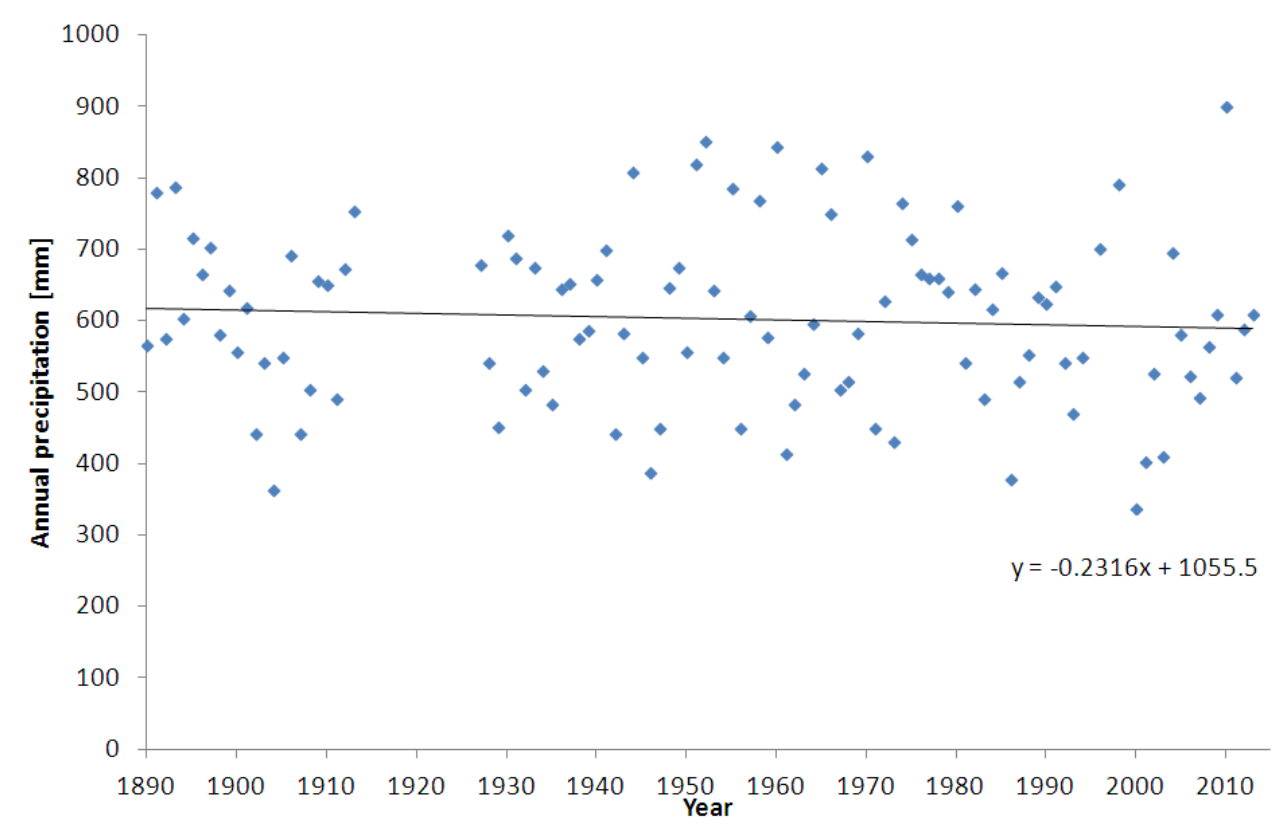

Figure 3. Amounts of annual precipitation between 1890 and 2013 in Hidasnémeti

On the analogy of annual precipitation amounts monthly precipitation from 1890 to 2013 were calculated and tendencies were verified (Fig. 4). As the graphically described monthly sectioning represents there is a certain decrease in precipitation volume besides of two separate months, February and June. Aridity in August and winter months catches everyone's eye. Thus, in accordance with former graph a reduction in precipitation amounts is clearly observable.

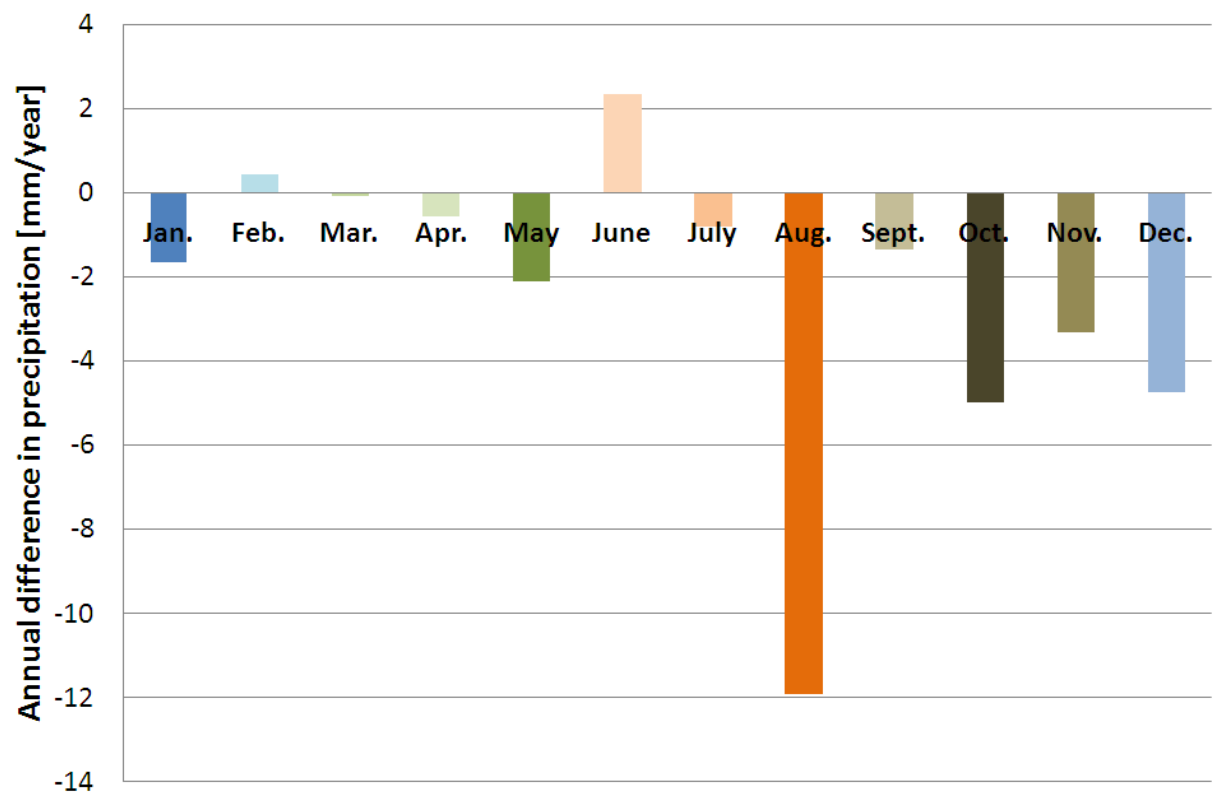

Figure 4. Total change of the amount of precipitation on monthly basis, between 1890 and 2013 in Hidasnémeti 
To study this tendency, this research was extended with one more aspect. The investigations related to reduction in precipitation amounts and tendency-analysing were carried out by adopting the WMO sectioning where each period includes 30 years. The gradients of the precipitation for the 30-year examination period were calculated, which were the degree of the variation in precipitation $[\mathrm{mm} / \mathrm{yr}]$. The gradient values were plotted against the beginnings of the examination period, separately for the months (Fig. 5). First period concerns a time frame 1890-1919, the next one 1981-1920, etc. Each study period appear in one-year offset. The last examined 30 years includes the years from 1984 to 2013, because of this, the last points can find above 1984 on the diagram. The graph below (Fig. 5) compares the figures for quantity changes in precipitation-periods of 30 years and the precipitation changes self. Regarding the investigated time period of a hundred and twenty-four years the reducing tendency in precipitation is obvious it does not matter from what directions graph data are analysed. Decrease began early 1930s touched the bottom in the middle of 1970 s approximately, and after a certain stagnation period it started growing towards zero. The local intensity was remarkable however the for last few years characteristic tendencies in terms of extreme weather conditions could not be recognised in this tendency as significantly.

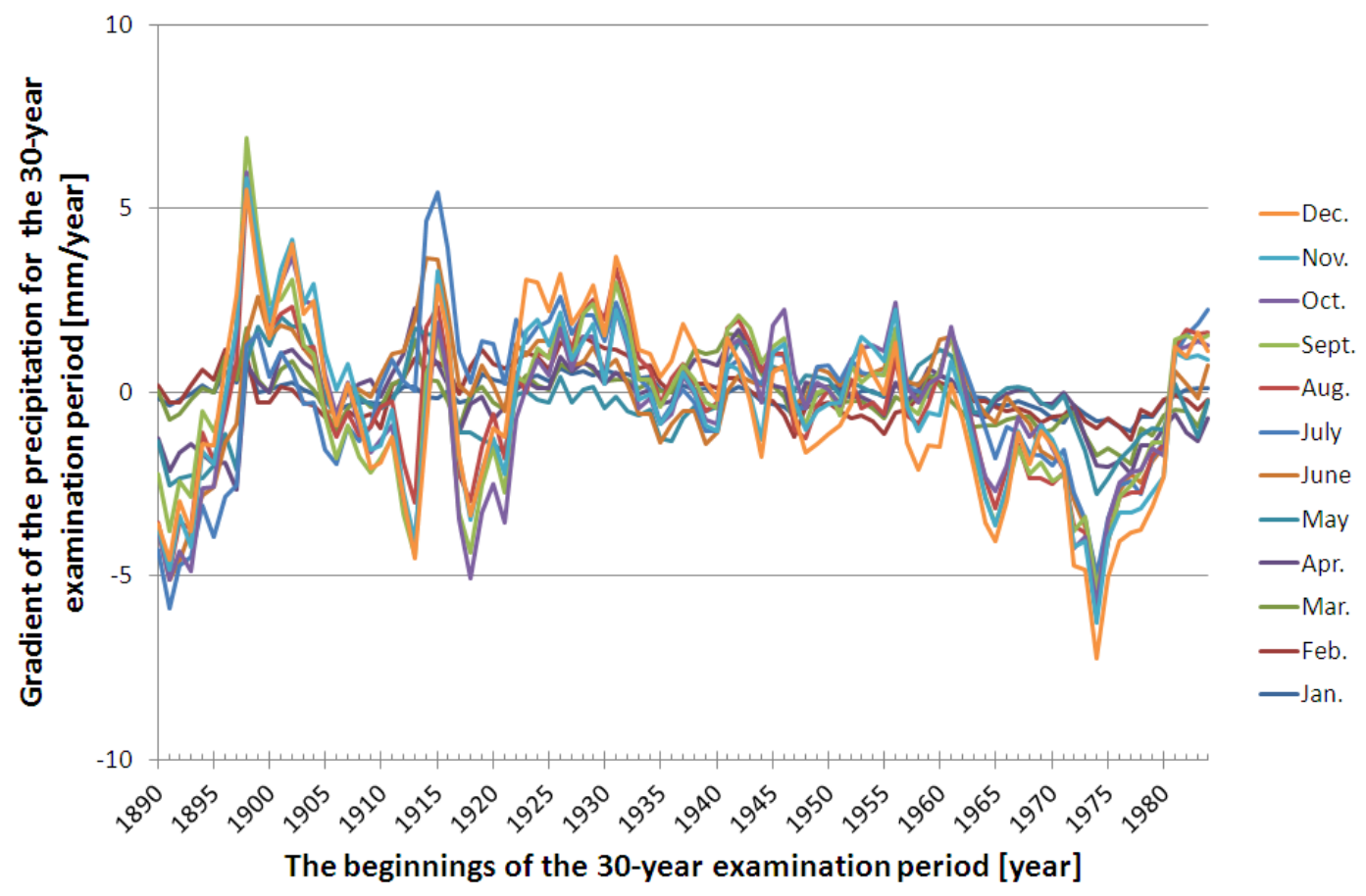

Figure 5. Tendencies of changes of precipitation on monthly basis

The experienced results by analysing precipitation amounts have been compared to values of water level-values of the relevant area. Data bases from the investigated sections have served as research pull to analyse daily water levels over last sixty five years. This period has offered sufficient sources to collect representative facts and figures. 


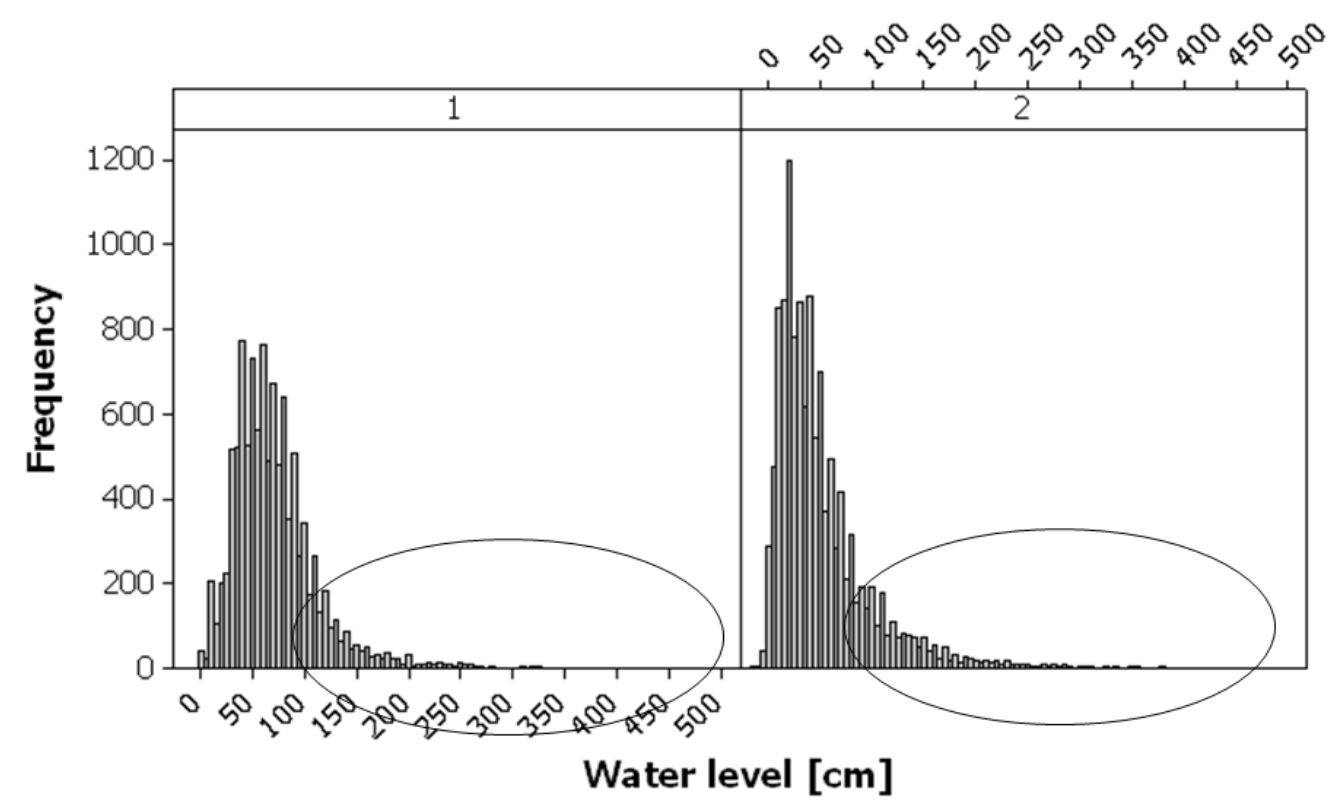

1: 1946-1975; 2: 1976-2011

Figure 6. Changes of values of water level on Hernád during the last 66 years

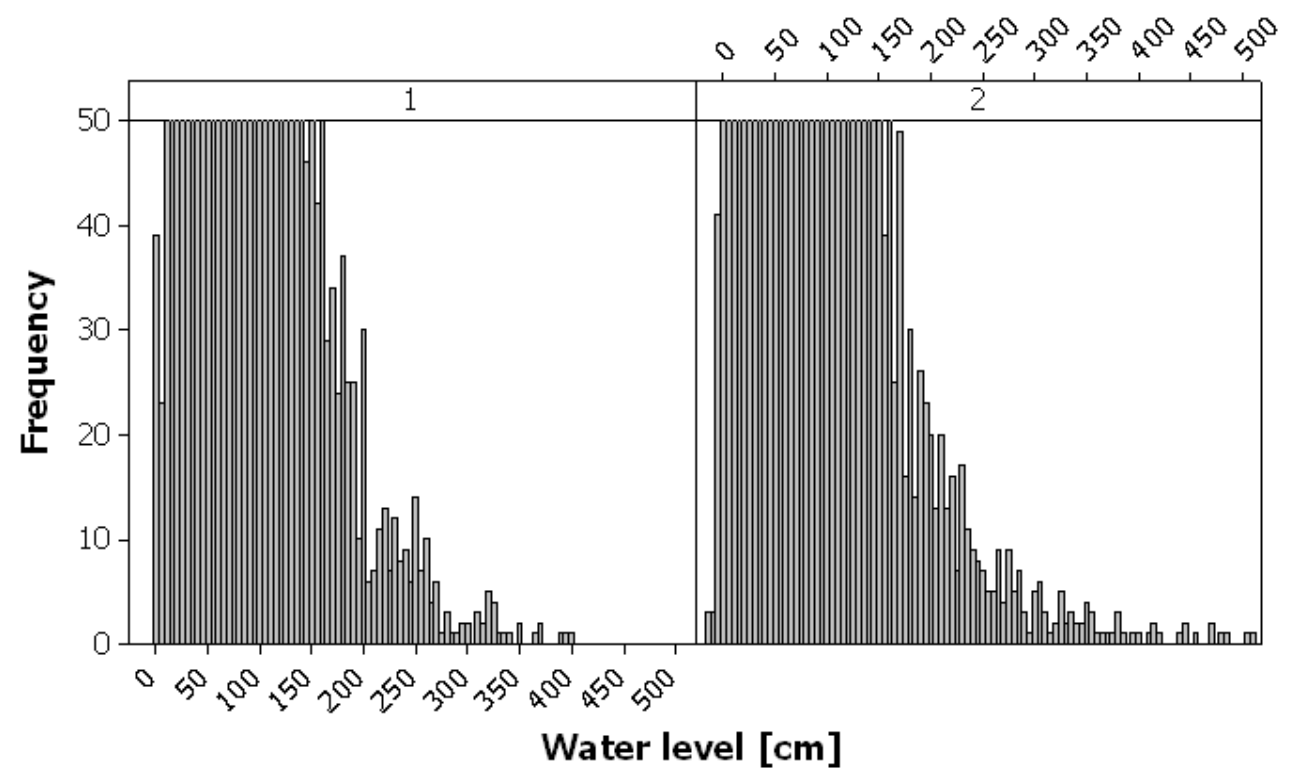

1: 1946-1975; 2: 1976-2011

Figure 7. Changes of maximum values of the water level on the Hernád (enlarged part of the circled part of Figure 6)

A histogram was created on the basis of daily water-levels and it indirectly generated an excellent tracking way to realize climate changes. Necessary data were divided into two periods, each of 30 years just as in the case of precipitation amounts. In comparison of data from 1946, the evaluating of chart data shows (Fig. 6-7) that water levels-values have been moved towards extremities in time. The applied statistic program offered 
space for new unique domains while processing data. This option performed as a single classification itself. Thenceforward, it was authors' duty to verify results. Taking a daily basis into consideration, the following water level-classifications were created: (-5)-5 $\mathrm{cm}, 5-10 \mathrm{~cm}, 10-15 \mathrm{~cm}$, etc. Results clearly show that water regime in first period (1946-75) is more balanced compared to the second period (1976-2011) when it moves towards more extreme values. Therefore, values of low water have remarkably grown just as the frequency of water-levels above $350 \mathrm{~cm}$. While comparing the results to locally experienced-climate variations, in terms of water-levels a significant movement has been approved towards low values (Fig. 6). The extremities of last fifteen years have been manifested in a growing frequency of high water (Fig. 7).

Concerning the relevant river sections both frequency and grades of flood-prevention measurements were investigated in the course of data-analysis. Especially those tendencies were examined, where changes in number of measurements and their grades reflected water-level modifications. In case of River Hernád, there are three categories or grades related to flood-prevention: first grade is suitable for the case when water level is $250 \mathrm{~cm}$ or above, second grade is necessary for water-level of $350 \mathrm{~cm}$ or above, and third, the highest grade is commanded in case of $450 \mathrm{~cm}$ water level or above (Fig.8). Changes are remarkable. The frequency of first grade has been decreased. Nevertheless, commands for second and third grades have been increased significantly.

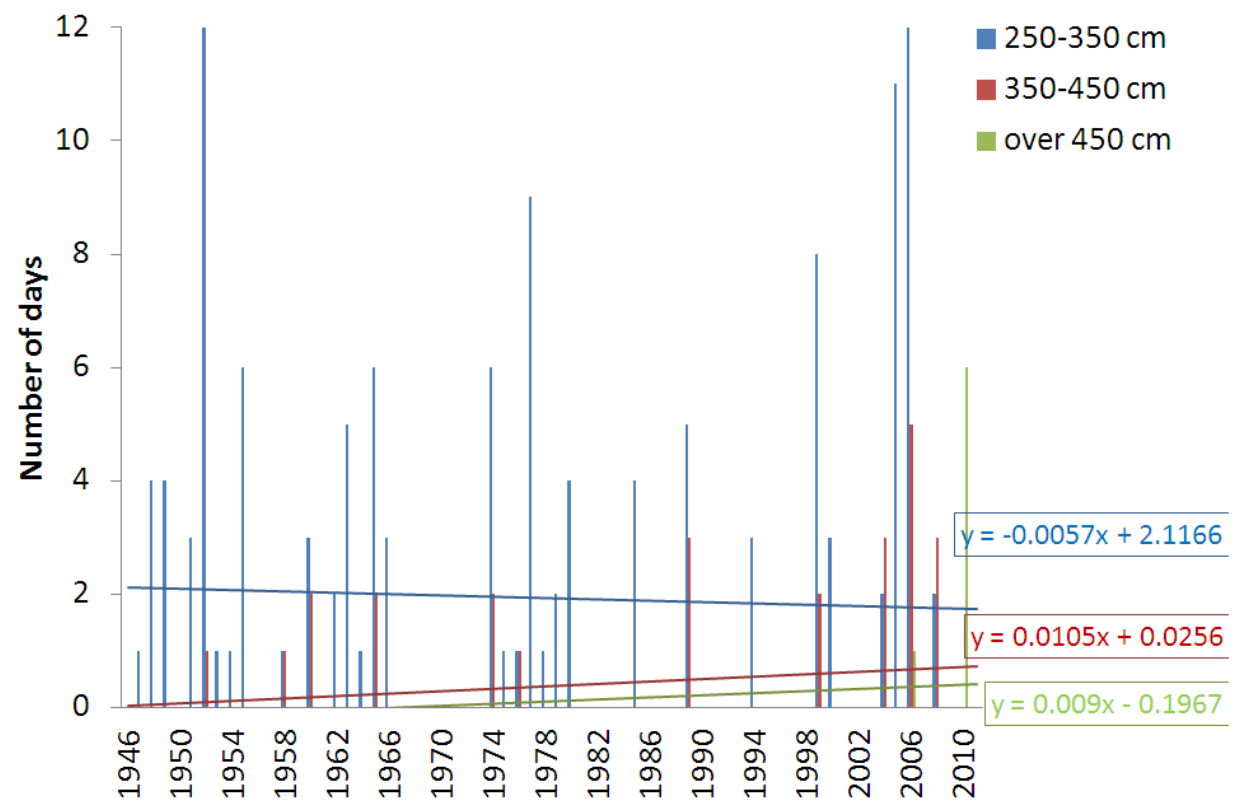

Figure 8. Changes of ordered flood gradation numbers during the last 65 years near Gesztely I.grade of flood prevention is 250-350 cm, II. grade of flood prevention is 350-450, III: grade of flood prevention over $450 \mathrm{~cm}$

This is in direct ratio to authors' results whereas the suddenly descending precipitation has a devastating impact by causing floods with a high water-level in a short time. The examinations rapport to an analysis performed in the area of Hidasnémeti a hundred years ago that figures of water outputs analysed. In essence, that had similar results (Konecsny, 2011; Szabó et al., 2011). The evaluations of data related to the river's water-level and water output have not resulted important differences in 
Hidasnémeti or Gesztely indeed, the same trends had been realized there. Consequently, the annual water-level minimum can be characterized with a descending tendency (approx. $1 \mathrm{~m}$ ) while the number of high waters is growing. Sziebert \& Zellei (2009) has been verified in a statement that the annual trend for high waters is slowly increasing. Last hundred years the flood level of river increased by approximately 2 meters. (According to a study published in 1933, the highest flood on Hernád took place in 1893. It was $306 \mathrm{~cm}$. In 2010, at time of great flood, a water-level of $503 \mathrm{~cm}$ was measured in Hidasnémeti and one of $517 \mathrm{~cm}$ in Gesztely.)

The decreasing tendencies in quantity of precipitation also appears in data concerning elevation of water, its moving average for 5 and 10 years indicates a strong correlation between precipitation values and water-levels (Fig. 9a-b). It is evidently established that the quantity of precipitation in the area has a direct or indirect impact on the elevation levels. That might powerfully influence even the shape of river-bed.

After having carried out morphologic researches in this area, authors were allowed to have some similar conclusions. In the course of examining the development of riverbed, the largest bank collapses (3-6 m) were rather experienced at a descent, shorter (about 3-4 weeks) water-level fluctuation $(50-60 \mathrm{~cm})$. In case of high water-levels, after extreme rainy periods, they were not as important (approx. $0.5 \mathrm{~m}$ or even zero). (Kozma, 2008; Kalmár \& Kozma, 2012), (Fig. 10) Regarding these results it can be concluded that a flood with a short descent period while remaining in river basin is increasing the speed of river. Thereby it destroys large parts of river banks. Sudden flood often undercuts, even washes away them and later on when, after a sudden water level-descent, their supporting function disappears, risks of leaning and collapsing become higher. Since the water-level changes generated by instantaneous floods are more frequent recently, degradation rates of river banks appear more significant.

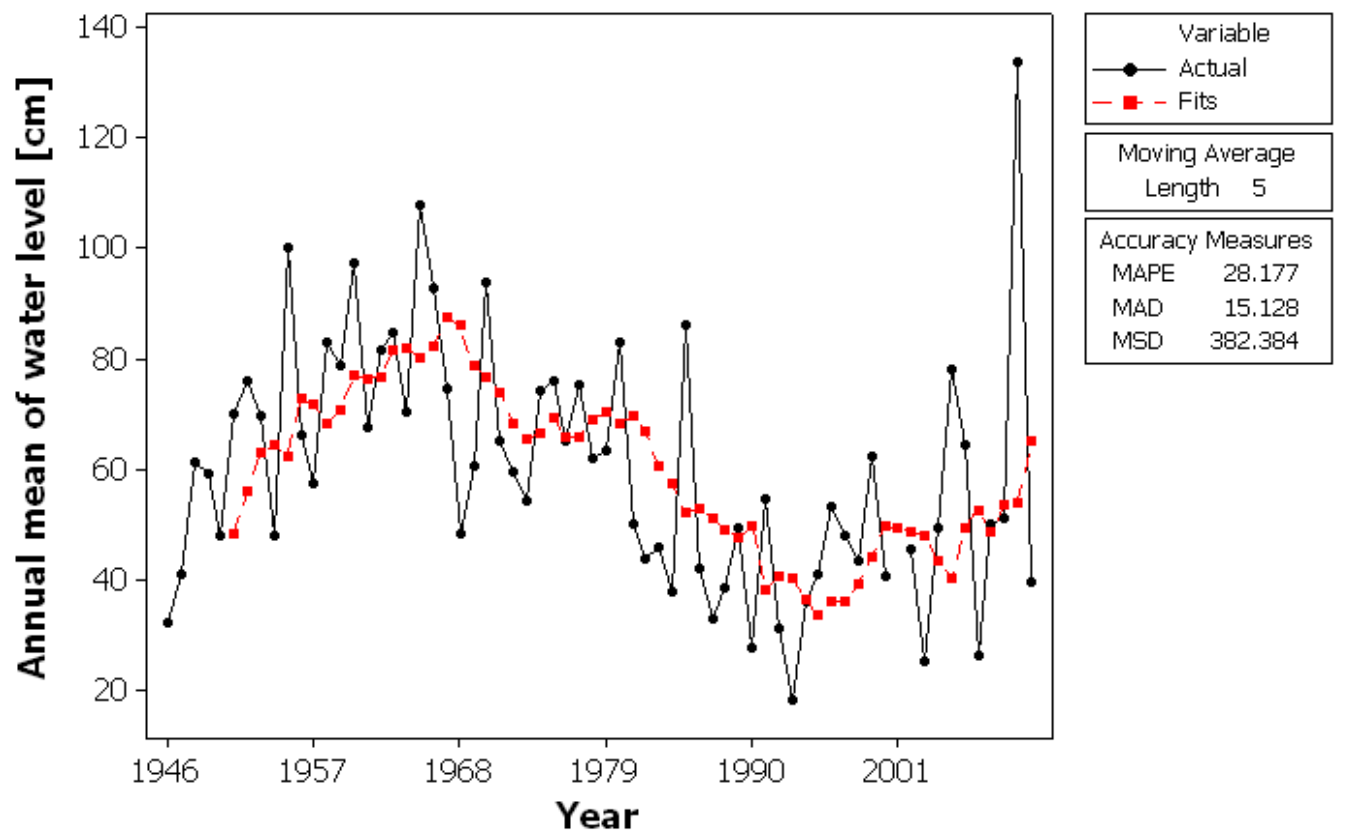

Figure 9/a. 


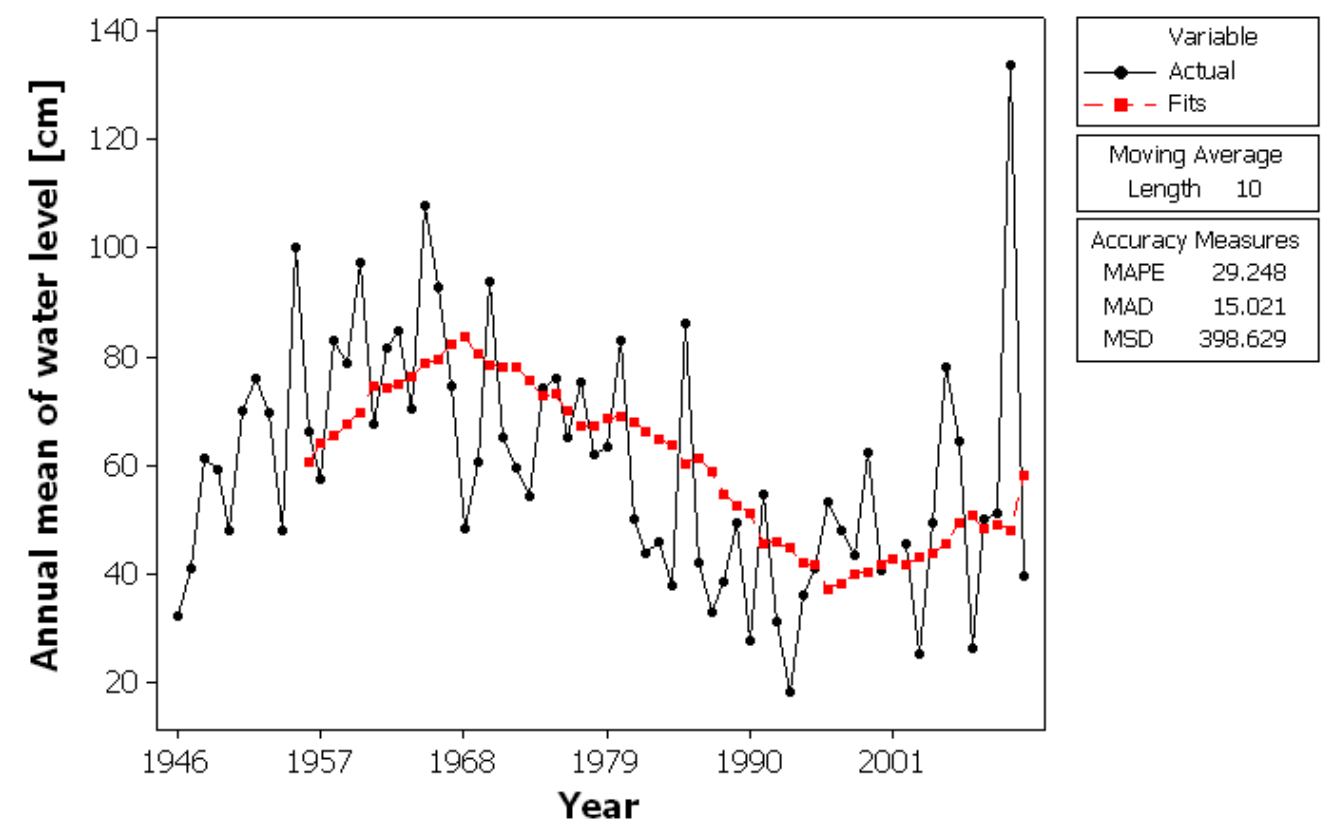

Figure $\mathbf{9 / b}$

Figure 9/a-b. Moving average of water levels of river Hernád from 1946

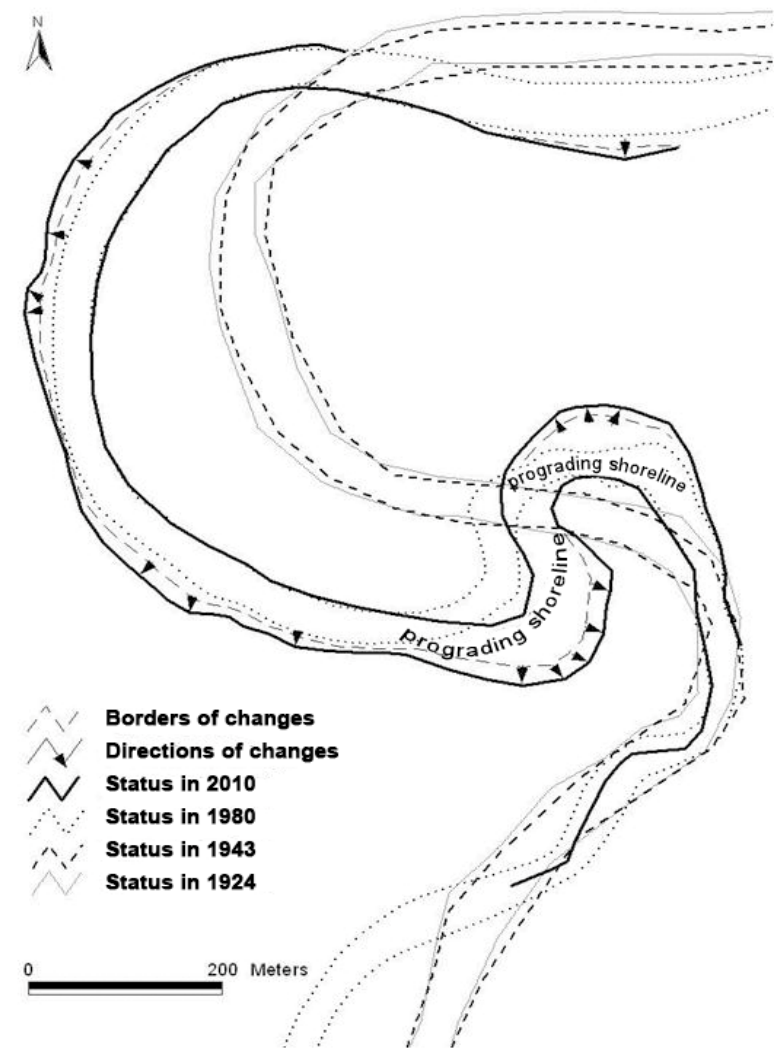

Figure 10. Developing of the meander on the research area 
The represented incidents and their effects are also strengthened by a modified landuse in the region. Last decades there was a strong transformation related to use of land in investigated areas. Territories used for pasturage or as meadowland, and orchard became stages for intensive agricultural activities. Nowadays, some parcels are reaching the riverside. Due to breaking natural vegetation, the "fastening" function of river banks perishes and it results in faster and larger devastation (Picture 1). On the other hand at those river sections where natural vegetation could remain and still covering river banks, a devastation process evoked by the river has had smaller dimensions (Picture2).

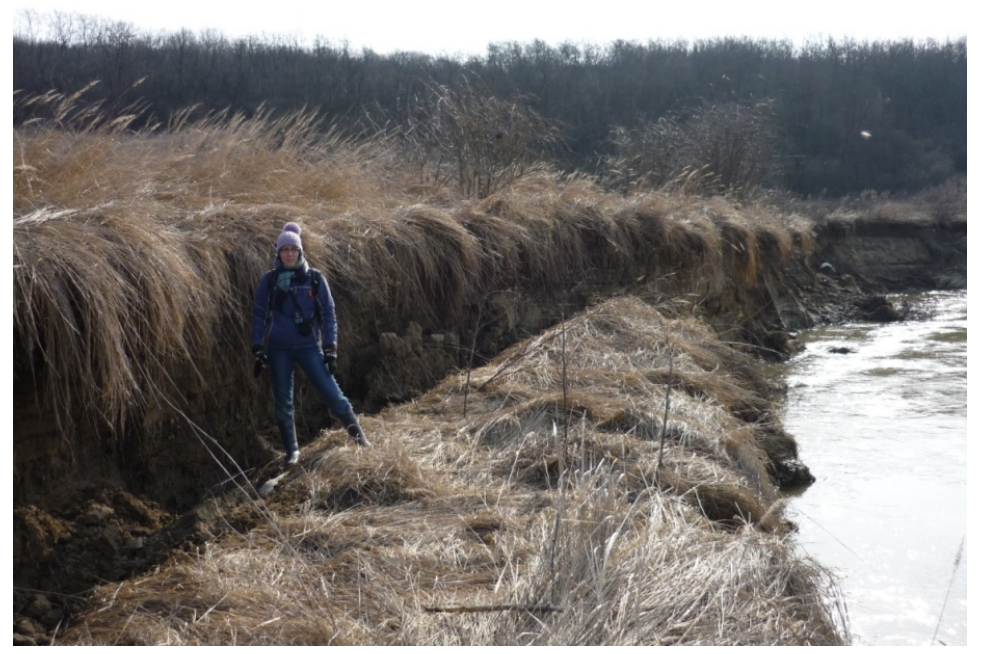

Picture 1. Block collapses along the river bank which covered by natural vegetation
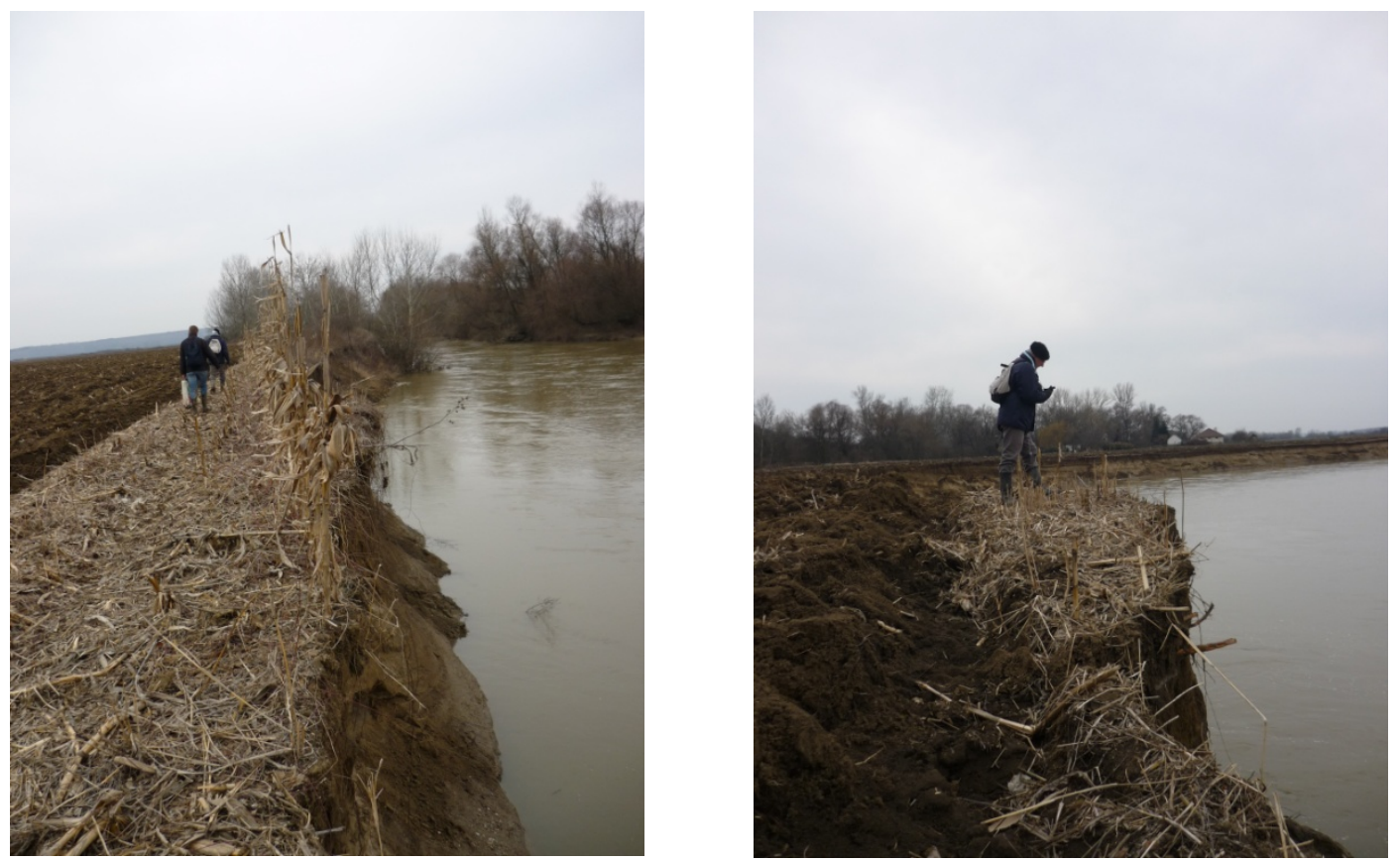

Picture 2. Strongly degrading river bank along the intensively cultivated agricultural land 
According to results of recent study, modifications occurred in use of land have even accelerated it. In such areas where land-uses are different, not only the intensity of devastation has been changed, also its forms can vary. In case of lands under a more intensive cultivation along high, steep river-banks, sudden bank-collapses or inclinations are more characteristic. This means that some coherent blocks or even whole vertical walls belonging to river-banks can break off suddenly and parts of the decaying blocks can fall into the river. Whereas in river sections with bank tracks and extensive bluffs, and covered by natural vegetation, massive river banks are more likely to collapse. In general, the longer fragmentation prepares their slower decay.

\section{Discussions}

Many influencing factors and their contributions have been studied while investigating the meandering activities of River Hernád. However, this circle should be extended for the sake of more appropriate results in terms of study topic. In case of River Hernád with its mainly meandering sections in Hungary, a great importance is attached to the examination of river-bed development as well as to tracking meteorological events and characteristics in the Hernád valley. Not only questions of theoreticians could be replied with more exact forecasts of prospective changes, but also flood prevention could become more efficient.

In general, a strong negative effect can be experienced across the whole Carpathian Basin namely there is a significant decrease in rainy days. In addition, this tendency can last longer (Horváth, 2009). Results of this study are likely to confirm these statements by analysing both direct and indirect effects on natural processes in the region.

Acknowledgements: Deep appreciation to Prof. Dr Tamás Réti for his potentials in the research field and support. OTKA tenders Nr. 042645 and Nr. 068897 allowed a great number of investigations in the field.

\section{REFERENCES}

[1] Bartholy J., Pongrácz R. (2005): Tendencies of extreme climate indices based on daily precipitation in the Carpathian Basin for the 20th century. - Időjárás 109: 1-20.

[2] Bartholy J., Pongrácz R. (2008): Regionális éghajlatváltozás elemzése a Kárpát-medence térségére. Analysis of the regional climate changes to the area of Carpathian Basin. In: Harnos, Zs., Csete, L. (eds.) Klímaváltozás: környezet-kockázat-társadalom, Budapest., pp. 15-54.

[3] Blanka V., Kiss T. (2010): A vízjárás hatása a parterózió mértékére a Hernád magyarországi szakaszán 2008-2010 között. Effects of the regime to the extent of the bank erosion in the hungarian part of the River Hernád, between 2008-2010. In: lóki, J. (ed.): Interdiszciplinaritás a természet-és a társadalomtudományokban, Debrecen, pp. 3744.

[4] Drégelyi-Kiss, Á., G. Drégelyi-Kiss, and L. Hufnagel (2008): Ecosystems as climate controllers - biotic feedbacks (a review). - Applied Ecology and Environmental Research 6(2):111-135.

[5] Horváth L. (2009): Alkalmazkodási kihívások és eszközök az éghajlatváltozási kerettörvényben. Adaptation challenges and methods in the law of climate changes. Tanulmány, p.35.

http://www.nfft.hu/dynamic/Alkalmazkodasi_kihivasok_es_eszkozok_az_eghajlatvedelm i_kerettorvenyben.pdf 
[6] Hajósy F., Kakas J., Kéri M. (1975): A csapadék havi és évi összegei Magyarországon a mérések kezdetétöl 1970-ig. Monthly and annual amounts of precipitation in Hungary in the period of the beginning of measurements till 1970. OMSZ kiadványa XLII. kötet., p. 355.

[7] IPCC - Climate Change 2007: The Physical Science Basis. Cambridge University Press, Cambridge, United Kingdom and New York, NY, USA, Annex I, p. 941.

[8] Kalmár, S. , Kozma K. (2012): A demonstration of the geomorphological value of radiocontrolled aerial vehicle imaging techniques in the study of the Hernád River. In: Zeitschrift für Geomorphologie 56. Suppl. 2., pp. 121-132.

[9] Kiss T.,Blanka V.,Sipos Gy. (2009): Morphometric change due to altered hydrological conditions in relation with human impact, River Hernád, Hungary. Zeitschrift für Geomorphologie 53. Suppl. 2., pp. 197-213.

[10] Konecsny K. (2011): A Hernád folyó vízjárási szélsőségei a XX. század második felében és a XXI. század első évtizedében. Regime extremes of River Hernad during the second part of XX. century, also included the first period of XXI. century. In: A magyarországi Hernád-völgy. Földrajzi Tanulmányok. Nyíregyháza-Szerencs, pp. 43-53.

[11] Kozma K. (2008): Recens folyóvízi fejlődés néhány kérdése a Hernád AlsódobszaGesztely közötti szakaszán. Some aspects of recent fluvial development in the section of Hernád between Alsódobsza-Gesztely. In: Szabó, J., Demeter, G. (eds.): Geographia generalis et specialis, Debrecen, pp. 155-160.

[12] Kozma K., Puskás J. (2012): Természeti és antropogén tényezők hatása a Hernád folyó medervándorlására. Effects of natural and anthropogenic factors on the meandering of River Hernád. VIII. Kárpát-medencei Környezettudományi Konferencia, Veszprém, pp. 188-193.

[13] Rakonczai J., Ladányi Zs. (2010): A sejthető klímaváltozás és a Duna-Tisza közi Homokhátság. The suspected climate change and the area of Duna-Tisza közi Homokhátság. - Forrás 42(7-8):140-152.

[14] Szabó J. (2008): Természeti értékek és veszélyek morfológiai példákkal. Natural values and hazards with morphological examples. - Földrajzi Értesítő 57(1-2): 125-134.

[15] Szabó J., Kozma K., Lóki J. (2011): Újabb adalékok a Hernád partfejlődéséhez. New supplements to the development of river bank of the Hernád. In: A magyarországi Hernád-völgy. Földrajzi Tanulmányok. Nyíregyháza-Szerencs, pp. 21-42.

[16] Szász G. (1994): Magyarország éghajlata és annak változékonysága. Climate of Hungary and its variability. In: Cselőtei, Harnos, Zs. (eds): Éghajlat, időjárás, aszály. Az időjárás változékonysága és hidrológiai vonatkozásai, Budapest, pp. 59-103.

[17] Sziebert J.,Zellei L. (2009): Hernád nagyvízi állapotainak vizsgálata ID hidraulikai modell alkalmazásával. Examination of high water conditions of Hernád with the using of ID hydraulics model. MHT XXVI. Országos Vándorgyűlés. Baja (CD, ISBN 978-9638172-23-5)

[18] Trummer Á. (1933): A Hernád mellékvizeinek rendezése. The channelization of tributaries of Hernád. - Vízügyi Közlemények 15: 111-166.

[19] VITUKI (1998): Regionális Vízgazdálkodási Terv a Hernád magyarországi vízgyüjtőjére. Regional Water Management Plan for the catchment of Hernád in Hungary. p.82. 